
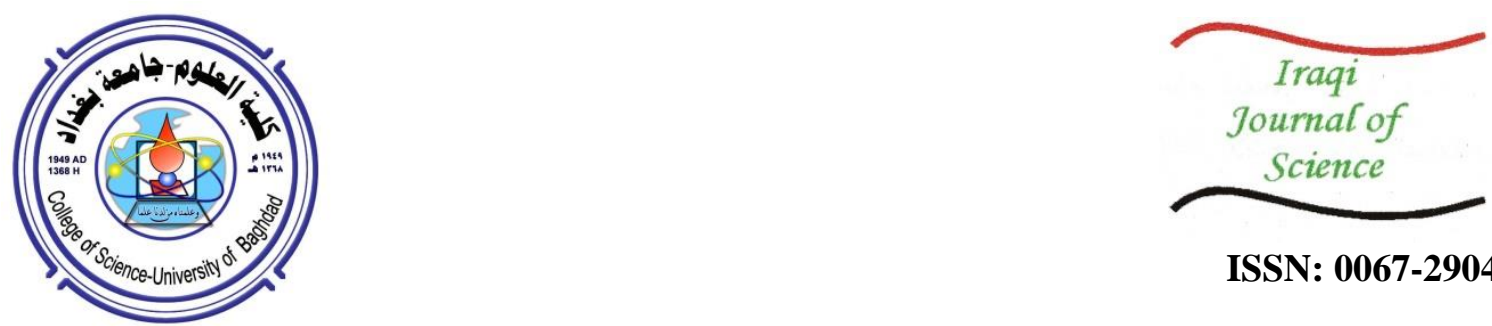

ISSN: 0067-2904

\title{
Molecular Study of Regulatory Gene (Ler) in Enteropathogenic Escherichia Coli (EPEC) of Diarrheagenic Patients
}

\author{
Mokhtar Jawad Kadhim AL-Imam*, May Talib Flayyih \\ Department of Biology, College of Science, Baghdad University, Baghdad, Iraq
}

Received: $23 / 9 / 2019$

Accepted: 23/12/2019

\begin{abstract}
The locus of enterocyte effacement LEE-encoded regulator (Ler) is a global regulator of multiple virulence genes expression in the Enteropathogenic Escherichia coli (EPEC), including those encoding the type III secretion pathway and adhesion proteins such as intimin. Ler is central to the process of the formation of the attaching and effacing (AE) lesions. This study aimed to perform the molecular detection of Ler gene in EPEC, since there is no related previous study in Iraq. Two hundred and fifty stool specimens from children under two years of age for both sexes were collected from some Iraqi hospitals. All isolates were diagnosed according to morphological characteristics and biochemical tests. The results showed that $140(56 \%)$ samples were identified as E.coli, while $8(5.7 \%)$ isolates were identified as EPEC as confirmed by using VITEK 2 system. Susceptibility test was determined for all EPEC isolates to 16 different antibiotics. The results showed that $100 \%$ of these isolates were resistant to Ampicillin, Cefazolin, Ceftriaxone, Cefepime, Trimethoprim and Ceftazidime, whereas resistance values to Nitrofurantoin, Cefoxitin and Gentamicin were $66 \%, 40 \%$, and $15 \%$ respectively. However $100 \%$ of the isolates were sensitive to Piperacillin, Ertapenem, Imipenem, Amikacin, Ciprofloxacin, Levofloxacin and Tigecycline. Monoplex pattern of PCR was used for detecting 16SrRNA, eae, stx1, lifA and Ler genes in EPEC. The results showed that the isolates of E.coli were positive for 16SrRNA, eae, lifA and Ler, while no bands of stx 1 appeared.
\end{abstract}

Keywords: EPEC, Intimin, 16SrRNA, Ler

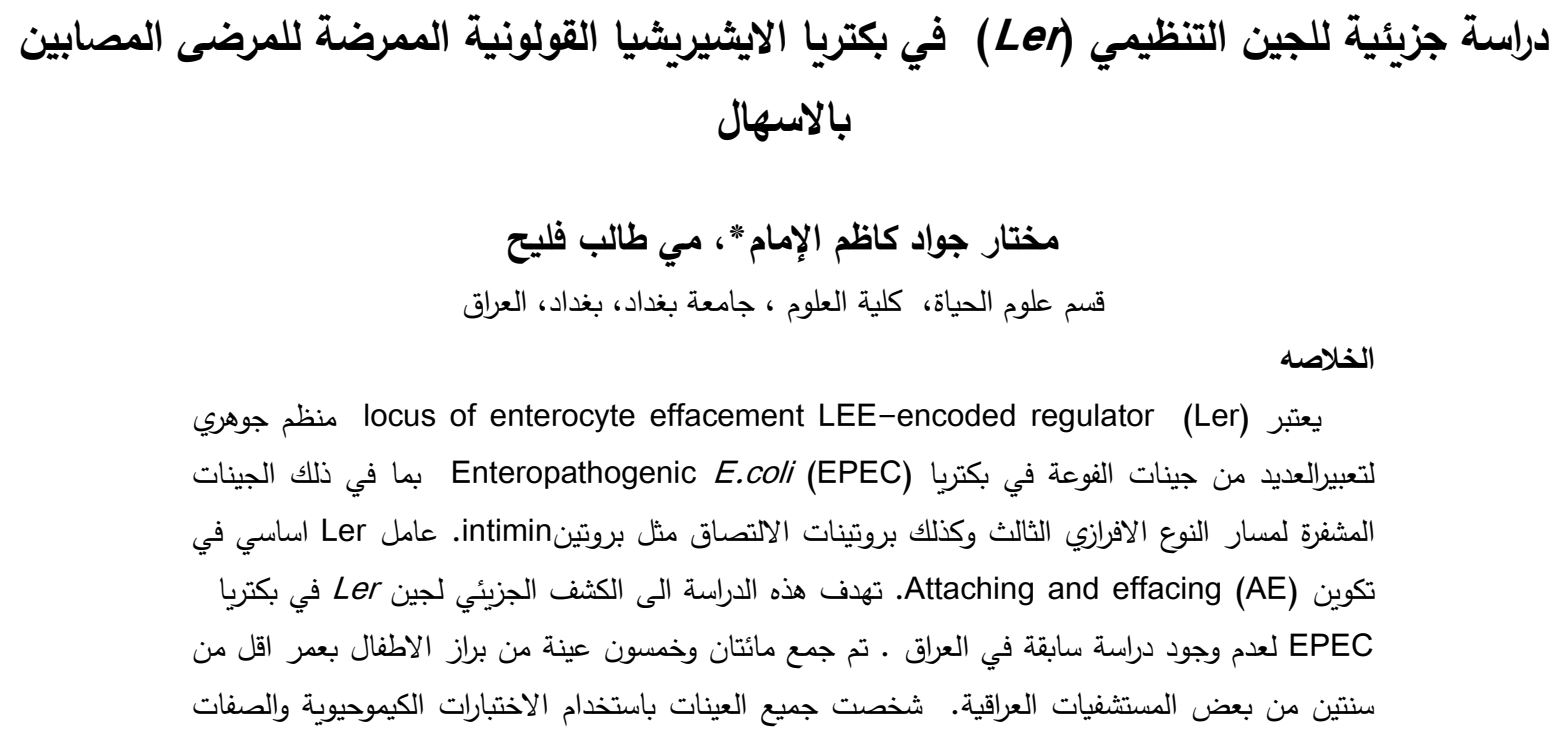

*Email: mukhtarjawad@yahoo.co.uk 


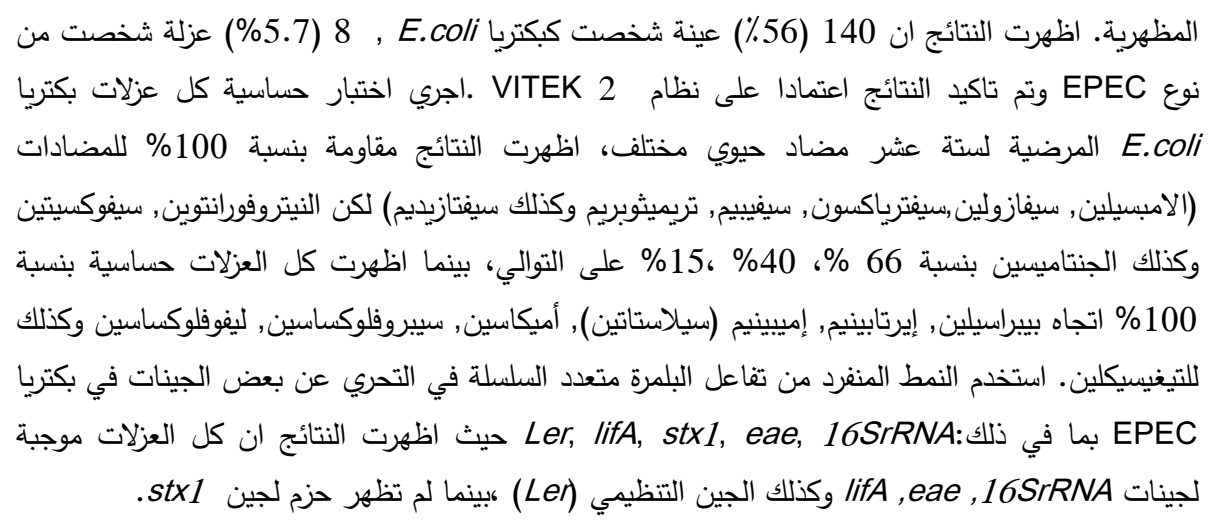

\section{Introduction}

Enteropathogenic Escherichia coli (EPEC) is a common cause of watery diarrhea in children in the developing world and an infrequent cause of significant diarrhea in adult patients [1]. It is divided into two types; typical enteropathogenic Escherichia coli (t-EPEC) are known to cause diarrhea in children. Atypical EPEC (a-EPEC) is called so since it lacks the bundle-forming pilus (bfp) gene that encodes a key adherence factor in t-EPEC. A-EPEC has another adherence factor called EHEC factor for adherence/lymphocyte activation inhibitor (efa1/lifA), which was strongly associated with diarrhea [2]. EPEC and EHEC share some virulence factors such as intimin, which is a key colonization factor in EPEC located on the locus of enterocyte effacement (LEE), EPEC causes watery diarrhea when colonizing the surface of enterocytes. The translocated intimin receptor facilitates tight adherence to epithelial cells and the formation of actin pedestals beneath EPEC [3]. a-EPEC is considered to be an emerging enteropathogen that is more prevalent than typical EPEC in developing and developed countries. The major adherence factor, intimin, an outer membrane protein encoded by eae, plays a pivotal role in the pathogenesis of a-EPEC [4]. LEE is a $35.6 \mathrm{~kb}$ pathogenicity island inserted in the genome of some bacteria such as EPEC. LEE comprises the genes responsible for causing attaching and effacing lesions, a characteristic type of lesions that involves intimate adherence of bacteria to enterocytes, a signaling cascade leading to brush border and microvilli destruction, and loss of ions, ultimately causing severe diarrhea. It is composed of 41 open reading frames and five major operons encoding a type three system apparatus, secreted proteins, an adhesion, called intimin, and its receptor called translocated intimin receptor (Tir) [5,6]. Secretion of effector proteins in EPEC is mediated by a specialized type III secretion system, the components of which are encoded in the LEE operons. The central regulator (master regulator) which controls the expression of LEE genes is Ler, a $15 \mathrm{kDa}$ protein encoded by the first gene of the LEEI operon. Ler is essential for the formation of A/E lesions, since nonpolar ler mutants of EPEC and EHEC were unable to form A/E lesions on host cells [7]. Based on all the information mentioned above, this study aimed to the isolation and identification of EPEC from patients with diarrhea under two years of age, detection of antibiotic susceptibility of E.coli isolates, and detection of the presence of some virulence determinants of EPEC and EHEC.

\section{Materials and Methods}

\section{Isolation and Identification of Enteropathogenic Escherichia coli}

From October 2018 to February 2019, 250 stool specimens from children under two years of age, for both sexes, were collected from Iraqi hospitals in sterilized containers. The diagnosis and characterization of E.coli were achieved according to their morphological properties on MacConkey agar, EMB medium, Sorbitol MacConky agar, and Kligler iron agar, as well as Oxidase production, Catalase production, Methyl red test, Indole production, Urease production, Vogeus Proskauer tests, Citrate utilization, and motility test [8-12].

\section{Molecular Study and Designing of Primers}

DNA extraction and purification were carried out by using genomic DNA purification kit protocol (Geneaid Extraction Kit). The concentration and purity of the extracted DNA sample were determined at $260 \mathrm{~nm}$ and $280 \mathrm{~nm}$. The results were recorded using computerization. The specific primers were designed according to Bio edit program and NCBI BLAST (http://www.ncbi.nlm.nih.gov) with conserved region (Table-1).

Table 1-The primers and their sequences used in conventional PCR 


\begin{tabular}{|c|c|c|c|}
\hline & Primer name & Sequence $5^{\prime} \longrightarrow 3^{\prime}$ & $\begin{array}{l}\text { Product } \\
\text { length }\end{array}$ \\
\hline 1. & 16SrRNA & $\begin{array}{l}\text { F:GATGACCAGCCACACTGGAA } \\
\text { R:GGAGTTAGCCGGTGCTTCTT }\end{array}$ & 213bp \\
\hline 2. & eae & $\begin{array}{l}\text { F:GGGCGGTCAGATTCAGCATA } \\
\text { R:CCATCACTGACTGTCGCACT }\end{array}$ & $741 \mathrm{bp}$ \\
\hline 3. & lifA & $\begin{array}{l}\text { F:TGGTCGGAGTCGTCCAGTAT } \\
\text { R:GGACGATGACCGATTTTGCG }\end{array}$ & 712 bp \\
\hline 4. & stx1 & $\begin{array}{l}\text { F:GTGTTGCAGGGATCAGTCGT } \\
\text { R:GACTCTTCCATCTGCCGGAC }\end{array}$ & 446 bp \\
\hline 5. & Ler & $\begin{array}{l}\text { F:ACCGCAATGAAGAAGGGCAGA } \\
\text { R:TTTCTTCTTCAGTGTCCTTCAC }\end{array}$ & 120bp \\
\hline
\end{tabular}

\section{PCR Amplification and determination of specificity}

The extracted DNA, primers, and PCR master mix were mixed together. PCR mixture was set up in a total volume of $20 \mu \mathrm{L}$, which included $5 \mu \mathrm{l}$ of PCR Green master mix, $1 \mu \mathrm{L}$ of each primer, and $2 \mu \mathrm{L}$ of template DNA. The remaining volume was completed with sterile de-ionized distilled water, then the mixture was vortexed. De-ionized water was added firstly, then the primers and DNA template were added. The negative control contained all materials except template DNA, instead of which distilled water was added. PCR reaction tubes were centrifuged briefly to mix and placed into thermocycler PCR instrument where DNA was amplified. The PCR program included 35 cycles, as follows: Initial denaturation at $95{ }^{\circ} \mathrm{C}$ for $5 \mathrm{~min}$, denaturation at $95{ }^{\circ} \mathrm{C}$ for $30 \mathrm{sec}$, extension at $72{ }^{\circ} \mathrm{C}$ for $40 \mathrm{sec}$, final Extension at $72{ }^{\circ} \mathrm{C}$ for $5 \mathrm{~min}$. The annealing stage was different for each gene, as follows: 16srRNA at $59.2^{\circ} \mathrm{C}$ for $30 \mathrm{sec}$, eae at $58.5^{\circ} \mathrm{C}$ for $40 \mathrm{sec}$, LifA at $58^{\circ} \mathrm{C}$ for $30 \mathrm{sec}$, Stx 1 at $61.6^{\circ} \mathrm{C}$ for $30 \mathrm{sec}$, and Ler at $60^{\circ} \mathrm{C}$ for 30sec. The PCR products were analyzed by using $2 \%$ agarose gel electrophoresis in $100 \mathrm{ml}$ of $1 \mathrm{x}$ TBE buffer and melted, then the agarose gel was cooled to $55-60^{\circ} \mathrm{C}$; the gel was stained by safe dye and $100 \mathrm{bp}$ DNA ladder. Then, the electric current was matched (70 volt for $1 \mathrm{hr}$ ).

\section{Results and Discussion \\ Isolation and identification}

The results of the present study recorded that $140(56 \%)$ out of 250 samples were identified as E.coli. Moreover $8(5.7 \%)$ out of these 140 isolates were identified as EPEC . The identification of EPEC was achieved according to culturing on Sorbitol MacConkey agar (SMAC), where the isolates gave pale colonies, as shown in Figure-1.

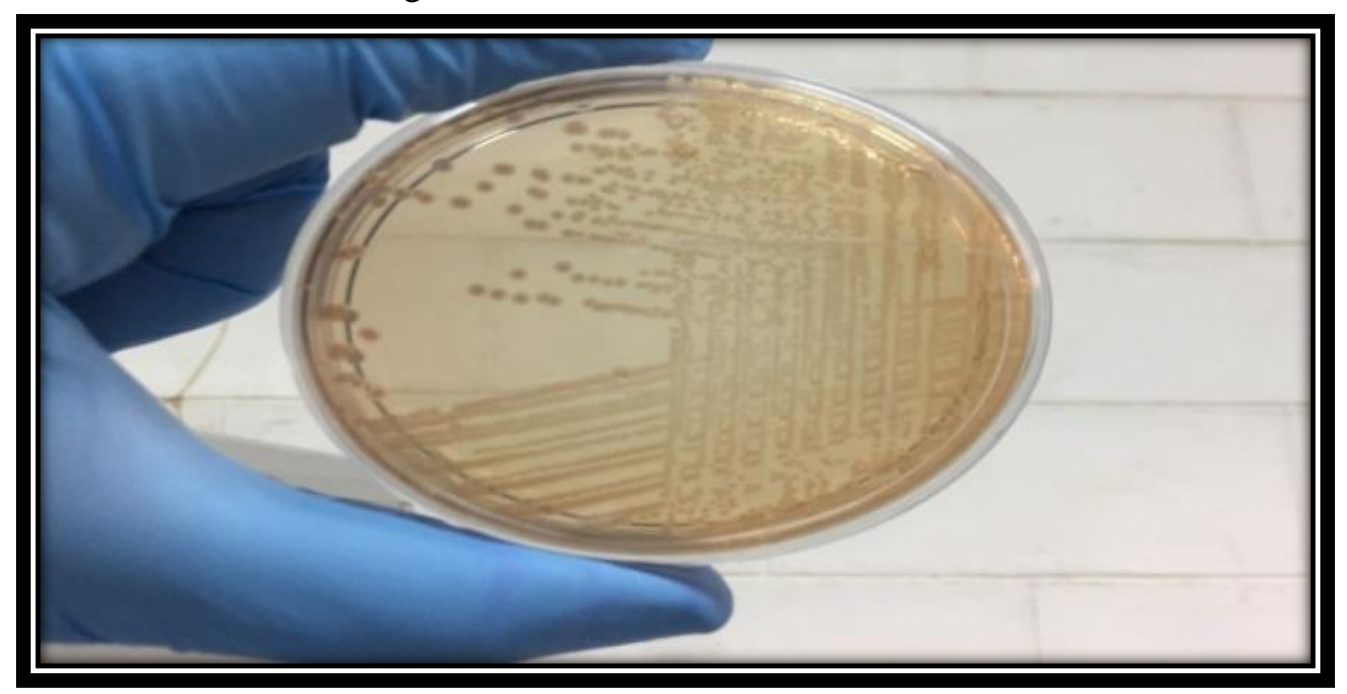

Figure 1-Pale colonies of Enteropathogenic E.coli on (SMAC)

The results of the present study revealed a high percentage of E.coli isolates in stool samples compared to other clinical isolates. The reasons of differences in the isolate percentages may be attributed to differences in season of collecting samples, as well as differences in the environment and 
the living area. However, the main reason might be that $E$. coli is the most common type of bacteria that normally live in the intestines of people and animals [13]. Our reason related to differences in the isolate percentages agrees with the explanation presented by Shakya et al. [14] . The high percentage of E.coli in stool refers to the fact that the resistance rates of $E$. coli isolates generally tend to be higher for hospitalized children, where pathogenic $E$. coli often dominate compared with other microorganism. In addition, 8 isolates were identified as EPEC in children with less than two years age. In developing countries, diarrhea is considered as a major cause of morbidity among children, which may be due to Escherichia coli [15]. A recent study suggested that children who are 12-24 months of age are more susceptible to infection than younger or older ones. This may be due to the antibodies acquired from the mother during pregnancy and the use of breastfeeding, both providing protection against many pathogens for small age groups. Changing dietary habits after the age of 24 months, with the use of complementary food, could cause acquired protection to be lost. In the early ages, the acquisition of natural immunity begins, which results in reducing the prevalence of diarrhea [16].

\section{Antibiotic susceptibility of pathogenic Escherichia coli isolates}

The results showed that $100 \%$ of Enteropathogenic E.coli isolates were resistant to Ampicillin, Cefazolin, Ceftriaxone, Cefepime, Trimethoprim, and Ceftazidime, while $40 \%$ were resistant to Cefoxtin, $15 \%$ were resistant to gentamycin, and $66 \%$ were resistant to nitrofurantoin. On the other hand, $100 \%$ of the isolates were sensitive to Piperacillin, Ertapenem, Imipenem, Amikacin, Ciprofloxacin, Levofloxacin, and Tigecycline, as shown in Figure-2. The results showed the high resistant of E.coli isolates to Ampicillin, and Trimethoprim. These results are in consistence with those of Vranic and Uzunovic [17]in a current study which showed $100 \%$ resistance of E.coli isolates to Cefazolin, Ceftriaxone, Cefepime, and Ceftazidime, . Similar results were also reported by Raeispour and Ranjbar [18]. Our results also showed the resistance of E.coli isolates to Gentamicin, which reached to $15 \%$, which is similar to the results of Hasvold and co-workers [19]. The resistance to Nitrofurantoin was 66\%, which is in agreement with Tulara [20], who reported a resistance of about 57\%, and with Aghemwenhio team [21]. While, resistance to Cefoxitin was 40\%, which is compatible with that shown by AbdelRahim and colleagues [22]. Resistant of E.coli isolates to Gentamicin reached to 15\%, which is comparable with the results of Hasvold and colleagues [23]. Our results showed that none of the isolates were resistant to imipenem, ciprofloxacin, amikacin, etrapenem, levofloxacin, piperacillin, and tigecycline, which is compatible with the results of Marejková and coworkers [24]. In general, bacteria resist the inhibitory actions of antibiotics through three primary mechanisms that often operate concurrently with each other. These include the decreased uptake, target modification, and inactivation of the drug. Resistance develops among microorganisms by spontaneous mutations in existing genes or by the acquisition of extraneous genes. The survival and success of resistant mutants is a matter of cost of fitness to the environment. Resistance is almost always plasmidic among E. coli; the contribution of porin and efflux-mediated mechanisms are negligible $[25,26]$.

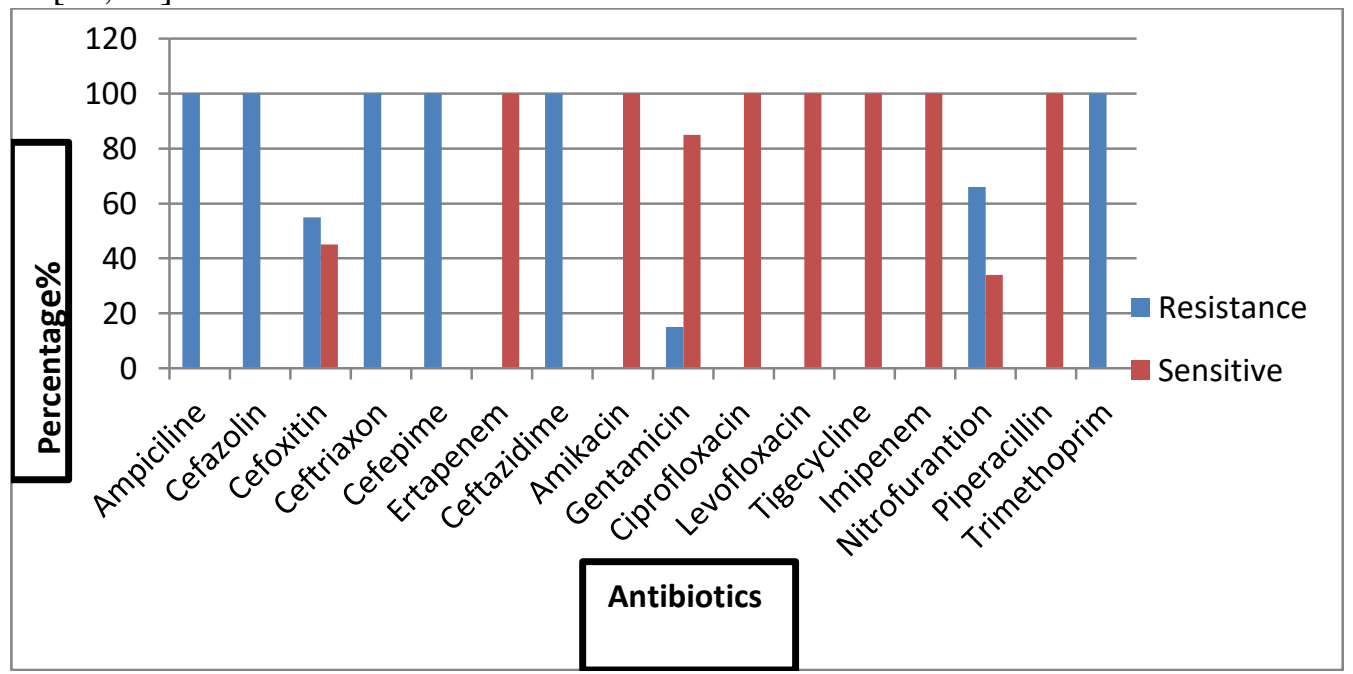

Figure 2-Percentage of antibiotic susceptibility for pathogenic E.coli isolates. 


\section{Molecular study}

The results revealed that the concentrations of DNA ranged $88-450 \mathrm{ng} / \mu \mathrm{l}$, while purity ranged 1.8 - 2. The current results also demonstrated that $100 \%$ of Enteropathogenic E.coli isolates had $16 \mathrm{SrRNA}$, eae, lifA, and Ler with sizes of $213 \mathrm{bp}, 741 \mathrm{bp}, 712 \mathrm{bp}$ and $120 \mathrm{bp}$, respectively, while all strains were negative for stxl gene(Figures 3-6).

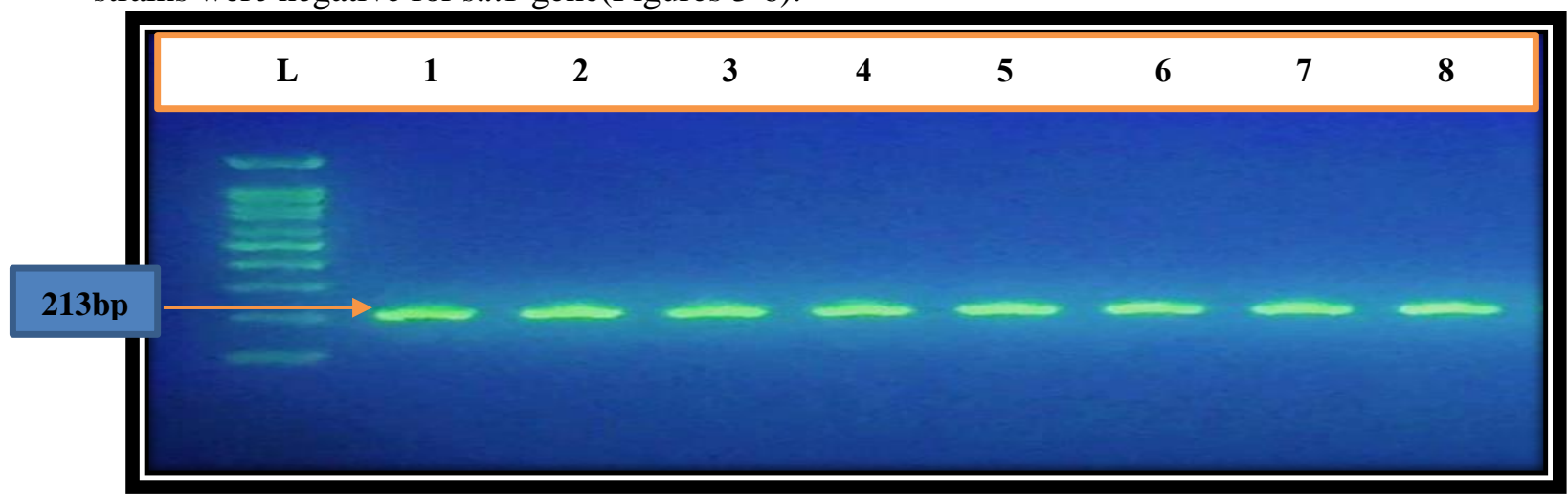

Figure 3-Amplification of $16 s R N A$ (213bp) from E. coli isolates on agarose (2\%), TBE buffer (1x), and 70 volt for 1 hrs Staining was performed with red safe. L: DNA ladder (100 bp); Lanes 1-8 were positive.

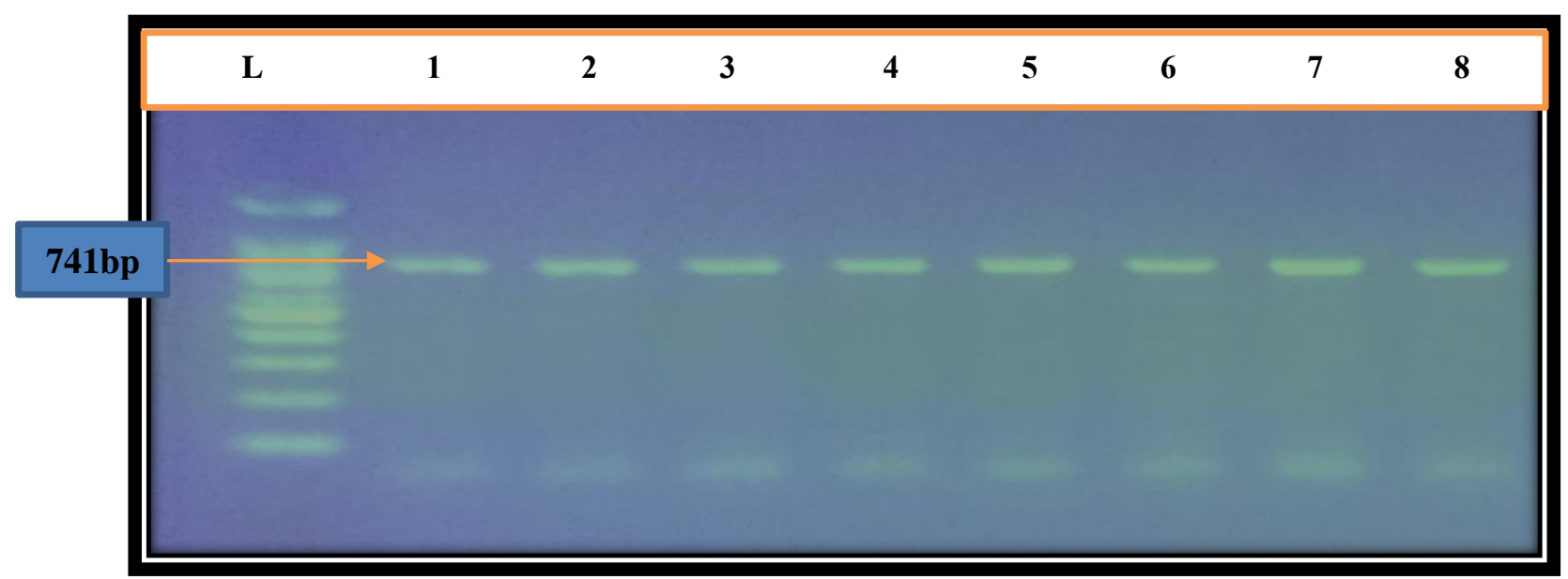

Figure 4-Amplification of eae (741bp) from E. coli isolates on agarose (2\%), TBE buffer (1x), and 70 volt for $1 \mathrm{hrs}$. Staining was performed with red safe. L: DNA ladder (100 bp); Lanes1-8were positive.

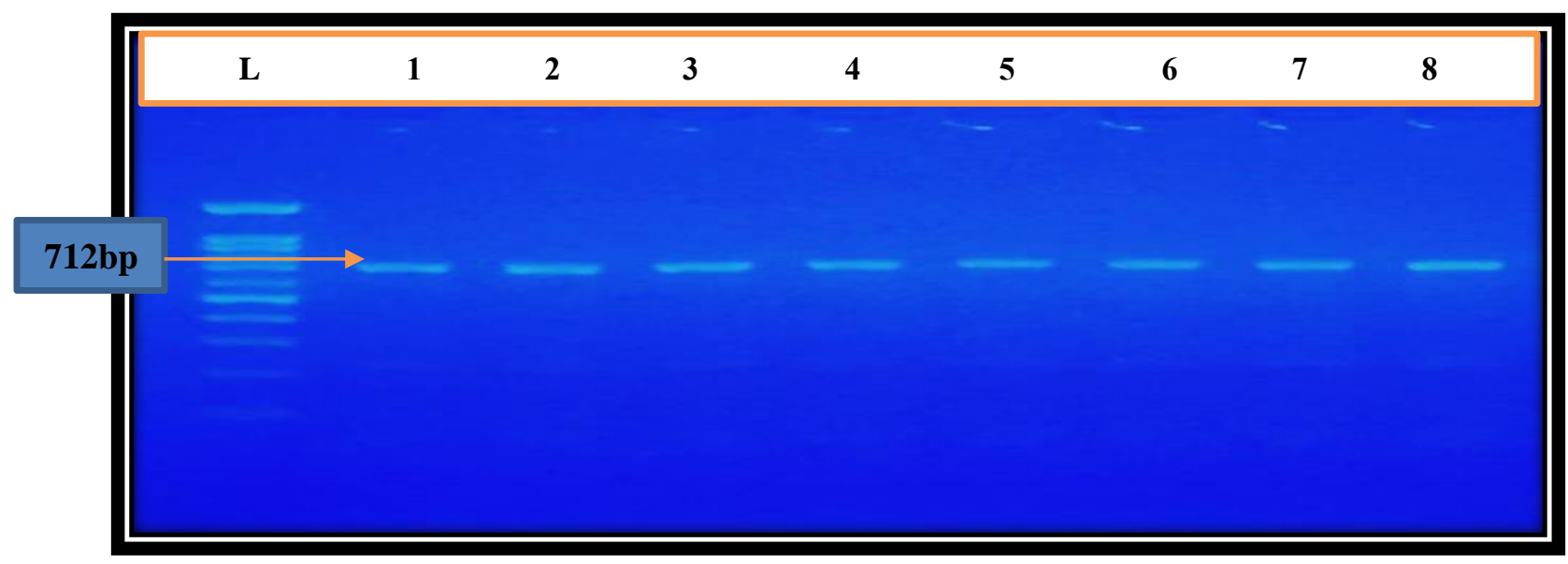

Figure 5-Amplification of lifA (712bp) from E. coli isolates on agarose (2\%), TBE buffer (1x), and 70 volt for $1 \mathrm{hrs}$. Staining was performed with red safe. L: DNA ladder (100 bp); Lanes1-8were positive. 


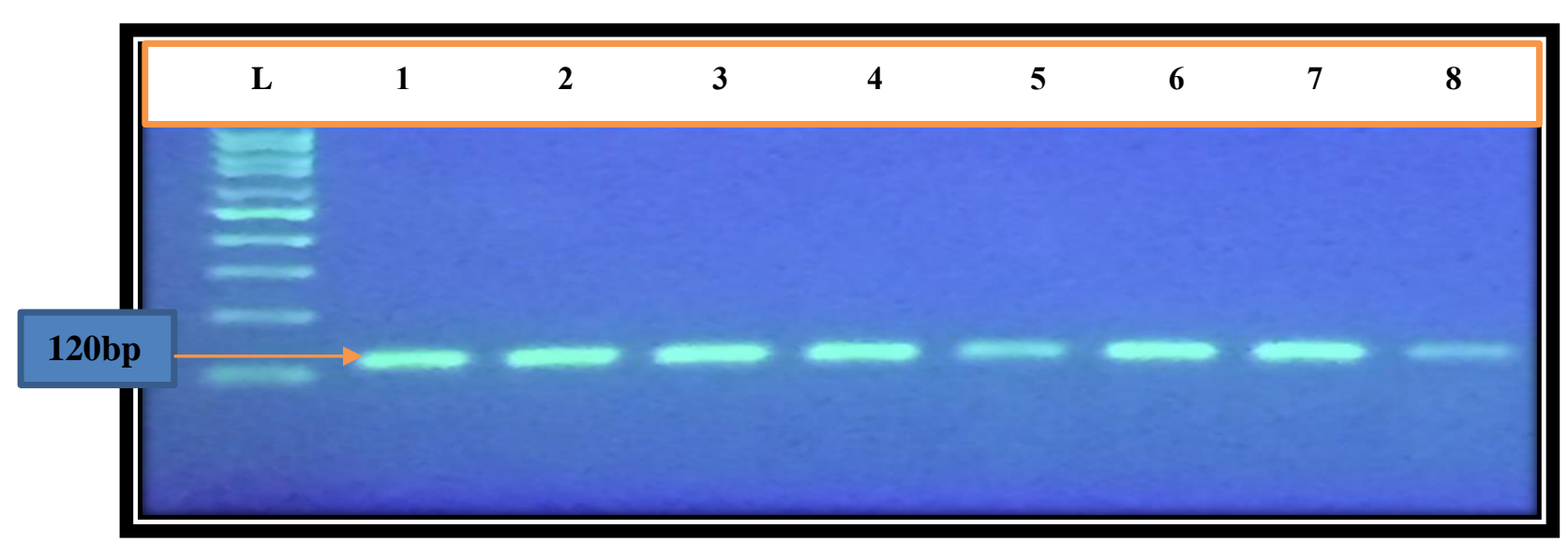

Figure 6-Amplification of Ler (120bp) from E. coli isolates on agarose (2\%), TBE buffer (1x), and 70 volt for 1 hrs. Staining was performed with red safe. L: DNA ladder (100 bp); Lanes 1-8were positive An amplification of $16 \operatorname{SrRNA}$ of isolates was performed to confirm bacterial identification.

The current results are similar to those of Suardana [27], who used 16SrRNA to detect Escherichia coli O157: H7. Our results are also similar to those reported by Kai and his colleagues [28] as well to those published by another study of AL-Imam and AL-Rubaii [29] who used 16SrRNA for the detection of gram negative Proteus spp.

The eae is the first recognized gene in the locus of enterocyte effacement (LEE) Pathogenicity Island. It is encoded by the polycistronic operon LEE5 and its product is a binding protein with the name of intimin. Intimin belongs to the outer membrane protein family produced by a group of EPECs and EHECs [30]. d'Auriac and Sirevåg [31] demonstrated that most EPECs are positive for eae gene, while another PCR study of 71 EPEC strains isolated from children with diarrhoea in Montevideo, Uruguay, showed that $57(80 \%)$ isolates carried eae gene (t-EPEC strains) [32]. The current study shows disagreement with a study published in 2015and involved the amplification of eae gene by multiplex PCR. The study revealed that 8 isolates (16\%) were possessing eae gene [33]. EPEC has lifA gene that acts on the inhibition of lymphocytes, with the strongest statistical association with diarrhea. Our results are also similar to those of Slinger and colleagues [34], who isolated 320 fecal samples which were tested positive for EPEC and showed that the efal/lifA gene was detected in EPEC. In China, a study collected stool samples from 2006 to 2015 in seven geographical regions. The study demonstrated that strains from diarrheal patients had significantly higher levels of efal (lifA) compared with other virulence factors, whereas the other strains were negative [35]. In addition, our results revealed that all the strains are negative for stxl gene, which is responsible for the production of shiga toxin (Stx) in enterohemorrhagic Escherichia coli (EHEC), while enteropathogenic E.coli so not produce stx 1 [36].

The current study was very interested in the detection of ler gene because the expression of $L E E$ genes is regulated by the transcription factor Ler, which is encoded by the ler gene, the first gene in the LEE1 operon. Few studies about ler provided stimulation for the design of a special primer for the gene. In Iraq, no previous study about the molecular detection of ler gene in EPEC and EHEC was published. Our study is compatible in terms of results with some studies worldwide that included the detection of ler gene expression in EHEC and EPEC. For example, a study published in 2014 investigated the role of iron pn LEE virulence gene expression in EHEC; the expression of LEE genes was greatly reduced in fur mutants irrespective of iron concentration. The expression of the ler gene was affected at a post-transcription step by fur mutation. Further analysis showed that the loss of fur affected the translation of the ler gene by increasing the intracellular concentration of free iron, while the transcription of the antisense strand was necessary for regulation. The results eventually indicated that LEE gene expression is closely linked to the control of intracellular free iron homeostasis [37]. Another study included the detection of ler gene and examined how the Ler regulator activates transcription of the divergent LEE2 and LEE3 operons, which have overlapping promoters in the 210 regions. Deletion analysis and gel shift experiments suggested that Ler activates both operons by binding to only a single region upstream of LEE2 that is located downstream of the transcriptional start site for LEE3 [38]. 


\section{Conclusions}

All Enteropathogenic E.coli were present in diarrheal stool samples of children under two years old, and several pathogenic E.coli were multidrug resistant. All Enteropathogenic E.coli isolates have the regulatory gene (Ler).

\section{References}

1. Denham, J. D., Nanjappa, S. and Greene, J. N. 2018. Treatment of Enteropathogenic Escherichia coli Diarrhea in Cancer Patients: A Series of Three Cases. Case reports in infectious diseases.

2. Slinger, R., Lau, K., Slinger, M., Moldovan, I. and Chan, F. 2017. Higher atypical enteropathogenic Escherichia coli (a-EPEC) bacterial loads in children with diarrhea are associated with PCR detection of the EHEC factor for adherence 1/lymphocyte inhibitory factor A (efa1/lifa) gene. Ann Clin Microb Anti, 16(1): 16.

3. Login, F. H., Jensen, H. H., Pedersen, G. A., Amieva, M. R. and Nejsum, L. N. 2018. The soluble extracellular domain of E-cadherin interferes with EPEC adherence via interaction with the Tir: intimin complex. The FASEB J, 32(12): 6860-6868.

4. Xu, Y., Bai, X., Zhao, A., Zhang, W., Ba, P., Liu, K. and Xu, J. 2016. Genetic diversity of intimin gene of atypical enteropathogenic Escherichia coli isolated from human, animals and raw meats in China. PLoS One, 11(3).

5. Leh, H., Khodr, A., Bouger, M. C., Sclavi, B., Rimsky, S. and Bury-Moné, S. 2017. Bacterialchromatin structural proteins regulate the bimodal expression of the locus of enterocyte effacement (LEE) pathogenicity island in enteropathogenic Escherichia coli. MBio, 8(4): 00773-17.

6. Franzin, F. M. and Sircili, M. P. 2015. Locus of enterocyte effacement: a pathogenicity island involved in the virulence of enteropathogenic and enterohemorragic Escherichia coli subjected to a complex network of gene regulation. Biomed Res Int.

7. Shin, M. 2017. The mechanism underlying Ler-mediated alleviation of gene repression by H-NS. $B B R C, \mathbf{4 8 3}(1):$ 392-396.

8. Harley, J. P. and Prescott, L. M. 2002. Bacterial morphology and staining. Laboratory Exercises in Microbiology, 5th Edition, The McGraw-Hill Companies, New York, 31-36.

9. MacFaddin, J. F. 1985. Media for Isolation-Identification-Cultivation-Maintenance of Medical Bacteria. Vol. I Williams and Wilkins, Baltimore. 1: 292-297.

10. Aneja, K. R. (2007). Experiments in microbiology, plant pathology and biotechnology. New Age International

11. Vandepitte, J., Verhaegen, J., Engbaek, K., Rohner, P., Piot, P., Heuck, C. C. and Heuck, C. C. 2003. Basic laboratory procedures in clinical bacteriology. World Health Organization.

12. Brenner, D. J.; Krieg, N. R. and Staley, J. T. 2005. (Eds.) Bergey's Manual of Systematic Bacteriology, Volume Two: The Proteobacteria. Part B: The Gammaproteobacteria. ${ }^{2 n d}$ Ed. Springer Science+ Business Media, LLC, 233 Spring Street, New York, NY 10013, USA.

13. Jang, J., Hur, H. G., Sadowsky, M. J., Byappanahalli, M. N., Yan, T. and Ishii, S. 2017. Environmental Escherichia coli: ecology and public health implications-a review. J. Appl. Microbiol, 123(3): 570-581.

14. Shakya, P., Barrett, P., Diwan, V., Marothi, Y., Shah, H., Chhari, N. and Lundborg, C. S. 2013. Antibiotic resistance among Escherichia coli isolates from stool samples of children aged 3 to 14 years from Ujjain, India. BMC infectious diseases, 13(1): 477.

15. Adegunloye, D. V. 2006. Carrier rate of enteric bacteria associated with diarrhoea in children and pupils in Akure, Ondo State, Nigeria. AJB, 5(2):162-164.

16. Ochoa, T. J., Ecker, L., Barletta, F., Mispireta, M. L., Gil, A. I., Contreras, C. and Cleary, T. G. 2009. Age-related susceptibility to infection with diarrheagenic Escherichia coli among infants from Periurban areas in Lima, Peru. CID, 49(11): 1694-1702.

17. Vranic, S. M. and Uzunovic, A. 2016. Antimicrobial resistance of Escherichia coli strains isolated from urine at outpatient population: A single laboratory experience. Mat Soc Med, 28(2): 121.

18. Raeispour, M., \& Ranjbar, R. 2018. Antibiotic resistance, virulence factors and genotyping of Uropathogenic Escherichia coli strains. Antimicrob Resist In, 7(1): 118.

19. Hasvold, J., Bradford, L., Nelson, C., Harrison, C., Attar, M. and Stillwell, T. 2013. Gentamicin resistance among Escherichia coli strains isolated in neonatal sepsis. JNPM, 6(2): 173-177. 
20. Tulara, N. K. 2018. Nitrofurantoin and fosfomycin for extended spectrum beta-lactamases producing Escherichia coli and Klebsiella pneumoniae. JGID, 10(1): 19.

21. Aghemwenhio, I. S., Timilehin, A. A. and Alpheus, G. A. 2017. Susceptibility of Beta-Haemolytic Eschericia Coli to Commonly Used Antibiotics in Selected Hospitals in Delta State, Southern Nigeria. Arch Clin Microbiol, 8 (2).

22. AbdelRahim, K. A. A., Hassanein, A. M. and El, H. A. 2015. Prevalence, plasmids and antibiotic resistance correlation of enteric bacteria in different drinking water resources in sohag, egypt. $J J M$, 8(1).

23. Hasvold, J., Bradford, L., Nelson, C., Harrison, C., Attar, M. and Stillwell, T. 2013. Gentamicin resistance among Escherichia coli strains isolated in neonatal sepsis. JNPM, 6(2): 173-177.

24. Marejková, M., Bláhová, K., Janda, J., Fruth, A. and Petráś, P. 2013 Enterohemorrhagic Escherichia coli as causes of hemolytic uremic syndrome in the Czech Republic. PLoS One, 8(9): 73927.

25. Andersson, D. I. and Hughes, D. 2010. Antibiotic resistance and its cost: is it possible to reverse resistance?. Nature Reviews Microbiology, 8(4): 260.

26. Ode, T., Saito, R., Kumita, W., Sato, K., Okugawa, S., Moriya, K. and Okamura, N. 2009. Analysis of plasmid-mediated multidrug resistance in Escherichia coli and Klebsiella oxytoca isolates from clinical specimens in Japan. IJAA, 34(4): 347-350.

27. Suardana, I. W. 2014. Analysis of nucleotide sequences of the $16 S$ rRNA gene of novel Escherichia coli strains isolated from feces of human and Bali cattle. J. Nucleic Acids.

28. Kai, S., Matsuo, Y., Nakagawa, S., Kryukov, K., Matsukawa, S., Tanaka, H. and Hirota, K. 2019. Rapid bacterial identification by direct PCR amplification of 16S rRNA genes using the MinIONTM nanopore sequencer. FEBS Open Bio, 9(3): 548-557.

29. AL-Imam, Mokhtar J. Kadhim and AL-Rubaii, Bahaa A. Laftaah. 2016. The influence of some amino acids, vitamins and anti-inflammatory drugs on activity of chondroitinase produced by Proteus vulgaris caused urinary tract infection. IJS. 57(4A): 2413-2421.

30. Franzin, F. M. and Sircili, M. P. 2015. Locus of enterocyte effacement: a pathogenicity island involved in the virulence of enteropathogenic and enterohemorragic Escherichia coli subjected to a complex network of gene regulation. Biomed Res Int.

31. d'Auriac, M. B. A. and Sirevåg, R. 2018. Multiplex PCR for the simultaneous detection of the Enterobacterial gene wecA, the Shiga Toxin genes (stx 1 and stx 2) and the Intimin gene (eae). BMC research notes, 11(1): 360.

32. Blanco, M., Blanco, J. E., Dahbi, G., Mora, A., Alonso, M. P., Varela, G. and Blanco, J. 2006. Typing of intimin (eae) genes from enteropathogenic Escherichia coli (EPEC) isolated from children with diarrhoea in Montevideo, Uruguay: identification of two novel intimin variants $(\mu \mathrm{B}$ and $\xi \mathrm{R} / \beta 2 \mathrm{~B}) . J M M, \mathbf{5 5}(9): 1165-1174$.

33. Crothers, J. L. D., Moore, J. E., Millar, B. C., Watabe, M. and Rooney, P. J. 2004. Determination of verocytotoxin and eae gene loci by multiplex PCR in Escherichia coli O157: H7 isolated from human faeces in Northern Ireland: a four-year study of trends, 1997-2000. Br. J. Biomed. Sci., 61(1): 1-7.

34. Slinger, R., Lau, K., Slinger, M., Moldovan, I. and Chan, F. 2017. Higher atypical enteropathogenic Escherichia coli (a-EPEC) bacterial loads in children with diarrhea are associated with PCR detection of the EHEC factor for adherence 1/lymphocyte inhibitory factor A (efa1/lifa) gene. Ann Clin Microb Anti, 16(1): 16.

35. Xu, Y., Bai, X., Jin, Y., Hu, B., Wang, H., Sun, H. and Xiong, Y. 2017. High prevalence of virulence genes in specific genotypes of atypical enteropathogenic Escherichia coli. Front Cell Infect Mi, 7: 109

36. Cheng, C., Balasubramanian, S., Fekete, A., Krischke, M., Mueller, M. J., Hentschel, U. and Abdelmohsen, U. R. 2017. Inhibitory potential of strepthonium A against Shiga toxin production in enterohemorrhagic Escherichia coli (EHEC) strain EDL933. Nat. Prod. Res, 31(23): 2818-2823.

37. AL-Mussawi, M. and AL-yasseen,A. 2015. Distribution of pathogenic Escherichia coli among children with severe diarrhea in Al-Najaf Al-Ashraf City, Iraq. Int. J. Sci. Res, 78-96.

38. Tobe, T., Yen, H., Takahashi, H., Kagayama, Y., Ogasawara, N. and Oshima, T. 2014. Antisense transcription regulates the expression of the enterohemorrhagic Escherichia coli virulence regulatory gene ler in response to the intracellular iron concentration. PLoS One, 9(7): e101582. 